直腸カルチノイド；症例報告と本邦報告例の文献的考察

\begin{tabular}{|c|c|c|c|}
\hline & 福岡大 & 1 外科 & \\
\hline 馬 & 純 孝 & 梅 野 & 寿 \\
\hline 島 & 正 和 & 志 村 & 秀 \\
\hline
\end{tabular}

\title{
RECTAL CARCINOID ; REPORT OF A CASE AND COLLECTIVE REVIEW OF CASES REPORTED IN JAPAN
}

\author{
Sumitaka ARIMA, Toshimi UMENO, Masakazu USHIZIMA, \\ and Hidehiko SHIMURA
}

The First Department of Surgery, School of Medicine, Fukuoka University, Fukuoka, Japan

われわれの集計し得た直腸カルチノイドの本邦報告例は42症例である.1970年以降の報告が多く，最近 の大腸疾患への関心のたかまりを示するのと思われる. 自験例を示すとともに，カルチノイド腫瘍の歴史 的背景の概略と, 集計例42症例について臨床病理学的検討を加兄, 診断と治療について述べた。男女比は 1.9 で男性に多く，40歳代にピークがあり，特異的な主訴はない。発生部位は肚門より直腸指䛦で可能な 症例が大多数で, 腫瘍の最大径により，1.0cm 以下では転移例はなく, $1.0 \sim 2.0 \mathrm{~cm}$ では $25 \%$ に, $2.0 \mathrm{~cm}$ 以上では $88 \%$ に転移がみられた。生化学的異常值を示した症例は 5 例にみられた。

索引用語：直腸カルチノイド，本邦報告例集計

I はじめに

カルチノイドは最近をで本邦では比較的まれな疾患と されて来たが，電子顕微鏡形態学的および生化学的分析 の進歩につれて, カルチノイドはセロトニン (5-HT) を始めとして，ヒスタミン，カリクレインなどを産生す る一種の functioning tumor として, 新しい観点より興 味をよんでいる.

Sanders $(1973)^{18)}$ は，1965年までの欧米論文より， 3,633 例の消化管カルチノイドを集計し, 直腸カルチ， イドは706例で, 虫垂, 小腸に次いで第 3 位の発生頻度 を示したとしている。

本邦では阿部の報告 $(1970)^{29)}$ があり，154例の全国集 計によると，気管支および虫垂に多く，それぞれ $27 \%$ 打 よび $25 \% て ゙ ，$ 次いで胃，值腸，小腸，十二指腸となって 括り，直腸は17例（11\%）を占めたとしている。

本邦報告例は欧米のそれに比べて，胃カルチノイドの 発生頻度が高いのに対し, 欧米では, 小腸カルチノイド が多くなって㧍り，カルチノイドの部位別発生頻度は， 人種により明らかな差異のあることを推定している。
しかし，発生藏器をみると，よく検查される部位， 症状の発現しやすい部位, よく手術される部位に多い傾 向にあり，また手術例と剖倹例との閒にも差異があるの で ${ }^{18)}$, 頻度の差異は本質的なるのかどらか, 今後の検討 をまつ必要があろう。

本論文では, カルチノイドの歷史的背景の概略と直腸 カルチノイドの自験例を示すとともに，本邦報告例42症 例について検討を試み，診断，治療について述べたい。

\section{II 歴史的事項および総説}

カルチノイド腫瘍の最初の報告は, 1838年 Merling ${ }^{1)}$ による虫垂癌としての記載が初めてである.その後, 1888年 Lubarsch' は,この Merling の報告した腫瘍の 詳細について記し，Lieberkuhn 腺營より発生すること を明らかにした。

1907年 Oberndorfer ${ }^{3)}$ は Merling や Lubarsch の記載 したものと同様の組織学的所見を呈する回腸の腫瘍を癌 と区別L, “Karzinoide Tumoren”なる名称を与えた。 1912年 Saltykow 4 は最初に直晹カルチノイドを報告 し, 迷入膵が他臟器で成育したものだと考えた。 
1914年には, Gosset \& Masson ${ }^{5)}$ が，このカルチノイ ド腫瘍細胞中に多数の嗜銀顆粒が含まれ， ammoniacal silver nitrate により黒染することより，argentaffin cell と称したためにカルチノイドは別名 argentaffin tumor ともいわれるよらになり，Masson はこの細胞を神経由 来と主張した，その後，その説が継承されてきたが，最 近, Pearse ${ }^{17)}$, 建石ら ${ }^{6)}$ の電顕的研究により, Kultschitzky 紐胞岕よび carcinoid 細胞内に証明される球形の分泌顆 粒は下垂体前葉の ACTH 産生細胞, Langhans 島細胞, 副腎髅質細胞などに諗められる神経内分泌顆粒と同一の むのであることより， carcinoid の神経細胞起原 (Neural crest origin) が主張されている.

1953年には Lembeck ${ }^{7)}$ により，この腫瘍から大量の serotonin が抽出され，さらにこれがいわゆるカルチ， イド症候群の本態であることが明らかになって以来，こ の腫瘍に対する関心が高まり, functioning tumor とし ての新しい展開がみられるようになった。

1963年 Williams ${ }^{8)}$ は発生学的にカルチノイドを, 前 腸型 (肺，胃，膵），中腸型（十二指腸，小腸，查腸， 横行結腸), 後腸型 (下行結腸, 直腸) に分類し, 後 腸由来の直腸カルチノイドは，前，中腸系と異なり， argentaffin, argyrophil 反応ともに陰性で, 5HTや, 5HTP を産生せず，尿中 5-HIAA も正常で，カルチ， イド症候群は呈さないとした。

1968年 Black ${ }^{9)}$ は Williams の考㝋をおし進めて, 電 影像より，直腸カルチノイドと正常直腸粘膜の enterochromaffin (KuItschitzky) 細胞では, 顆粒, ミトュンド リア，その他の構造が非常に類似しており，発生学上同 じものであろらし，ともに顆粒は argyrophil 反応にも argentaffin 反応にも陰性で, 比較的大きく $(190 \mathrm{~m} \mu)$ 均 一でまるく, 種々の density を有し, 他の臟器 (前, 中 腸由来)の kultschitzky 細胞や carcinoid 細胞とは異な っているが，後腸系葴器にも少ないながら，argyrophil pargentaffin 反応陽性の Enterochromaffin 細胞が存在 しており，同細胞より反応陽珄の直腸カルチノイドむ発 生し, カルチノイド症候群を呈しらる可能性を指摘して いる.

曾我 ${ }^{10)}$ はさらに, 人カルチノイド多数例の組織学的, 組織化学的分析によって, Williams らの分類の合理性 を確かめている。

最近, Masson, 建石等の神経由来説に対して, Carcinoid のある症例は腺管形成や粘液産生能を示す部分を含む症 例が報告され(112)13)，また分化した腺癌の 1 部に carci- noid への移行像が認められたことより $\left(\right.$ Tocker $\left.^{14)}\right)$, そ の母細胞は, argentaffin cell と考えるよりも, 多方向 へ分化能を有与る末分化細胞より発生したと考穴る方が より妥当であるうとする考えるあり，これを支持するる のとして Kubo ら ${ }^{15)}$ は通常の胃癌の3.1\%, 大腸癌の2.5 $\%$ に銀親和性細胞を認め, Watanabe ${ }^{16)}$ は胃の腺腫(異 型上皮）の50\%近くに上記細胞の出現を認めている。し かしカルチノイド腫瘍の組織発生についてはいまだ明確 な結論を得ていないのが現状である。

\section{III 症例}

患者: 62歳, 今.

主訴：とくにない。

家族歴：特記すべさことはない。

現病歴：若い頃より心窩部不快感があった. 昭和47年 10月30日, 胆のう蓄膿症で急患として来院し, 外来受診 時, 面腸指診にて面腸膨大部に拇指頭大の腫瘍を指摘さ れ，生検で直腸カルチノイドと診断された。

胆石症の手術後昭和48年 1 月 8 日再入院した. 自覚症 状は全くなく, 顔面紅潮, 気管支喘息様呼吸困難, 心悸 兄進, 下莉, 腹痛等のカルチノイド症候群を思わせる症 状はなかった。

入院時所見：体格中等度，栄養良好，体重 $57.5 \mathrm{~kg}$, 血 圧 $110 / 80 \mathrm{mmHg}$.

顔貌は正常で, 貧血, 黄疸なく，頝部リンパ節腫脹も 認めなかった。

胸部は打診, 聴診上異常なく，心音は純であった。腹 部は平坦，軟で肝，腎，脾は触れず，右季胁部に胆のう 切除時の腹直笳切開創瘢痕がみられる以外, 腫瘍は触知 しなかった。

直腸指診：外見上特に異常は認めず, 肛門輸の緊張状 態良好. 肛門輸より約 $6.0 \mathrm{~cm}, 7$ 時の部分に立ら上がり 急峻な広基性，拇指頭大の腫瘤を触れ，中心に陥凹があ り，硬く動きが悪かった。

入院時諸検查: 表1のようにとくに異常はなかった が，Al-p の上昇がみられるのは，胆石症術後のためと 考壳られ，退院後は正常化していた．肝シンチでるとく に異常欠損像はなかった。

血中セロトニンは $3.9 \mathrm{mcg} / \mathrm{dl}$ ，尿 5-HIAA $4.2 \mathrm{mg} / 24 \mathrm{~h}$ と正常範囲内であった。

肛門直腸鏡検查 : 肛門輪より $6.0 \mathrm{~cm}, 7$ 時に立ち上が り急峻で広基性の中央に潰瘍のある約 $2.0 \mathrm{~cm}$ 径の隆起 珄病変が見られ，潰瘍部は少し赤味を帯びているが，表 面の粘膜は周囲とほとんど変らず，とくに黄味を帯びて 
表 1 入院時諸検査

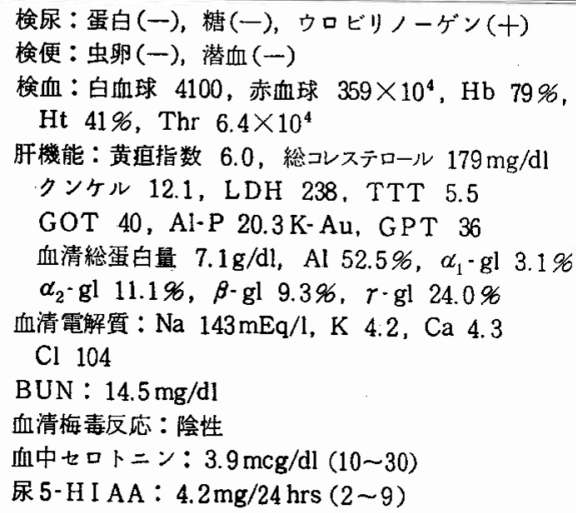

いることはなかった. 生検時, コッコッした感じで非常 に硬く，動きが悪かった。

生検により直腸カルチノイドと診断されたが，(1) 腫 痬の大きさが約 $2.0 \mathrm{~cm}$ あること，(2) 潰瘍化がみられ ること, (3) 生検時, 腫瘍の動きが悪く, 筋層への浸潤 が疑われたことにより根治的手術を施行した。

開腹時所見 : 下腹部正中切開にて開腹した.

腹水の貯溜はなく，触診上, 肝, 局所リンパ節に転移 らしいものはみられなかった。

術式は腹会陰合併直腸切断術（Miles）を施行した。

切除標本 : 結腸間膜例より ( 6 時) 開いたものである が, 直腸膨大部に $1.8 \times 1.5 \mathrm{~cm}$ の正常粘膜に覆われ，中心 に潰瘍を有する浪济半球状の腫瘤がみられる(図 1，2）.

割面の図 3，4 亿示すように白黄色の腫瘤が正常粘膜 を押し上げるように粘膜下層を占め，図5 のよう飞筋層 を強く下方へ闰排している。

\section{図 1 切除標本全体}

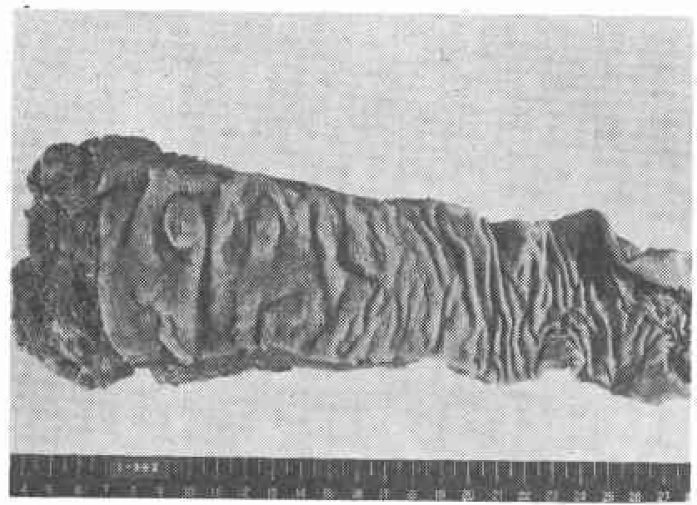

図2 直腸膨大部に $1.8 \times 1.5 \mathrm{~cm}$ の正常粘膜に覆わ れ中心に潰瘍を有する半球状の腫瘤がみられる。

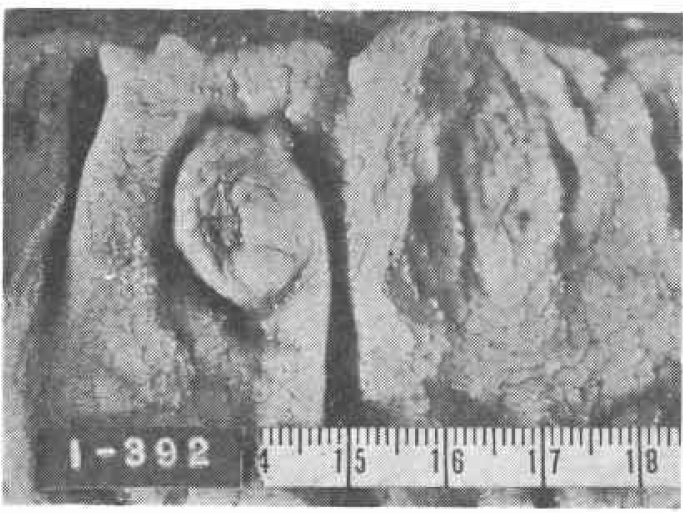

図 3 連続切片

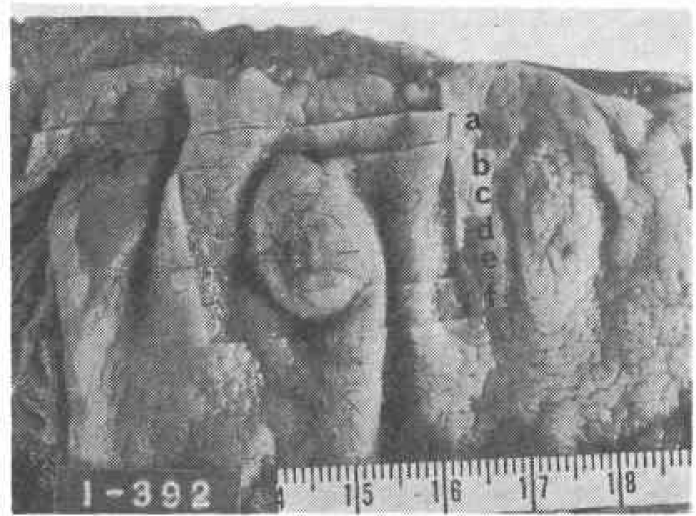

図 4 連続切片：割面，腫瘤は白黄色を呈す。

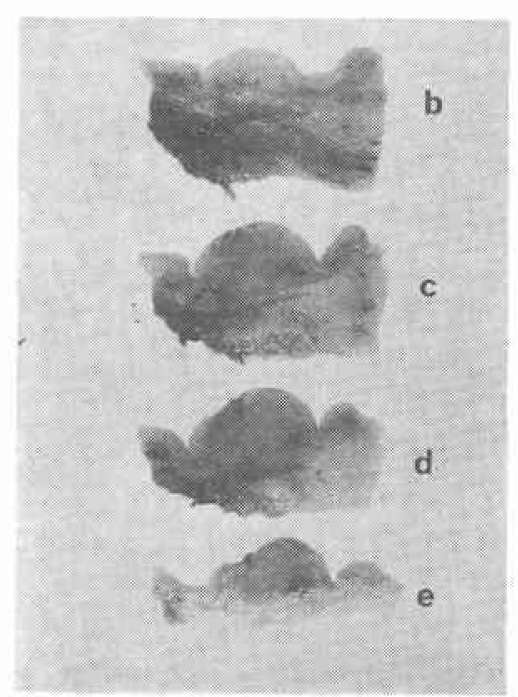


図 5 腫瘤最先進部、筋㸴を強く下方へ王排寸。 $\mathrm{HE} \times 9$

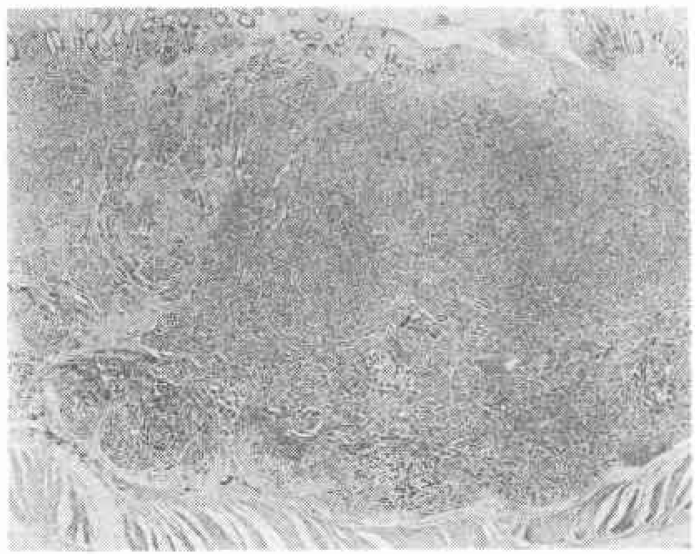

図 6 腫簜細胞は、リボンないし花綱状排列が明瞙 $\mathrm{HE} \times 192$

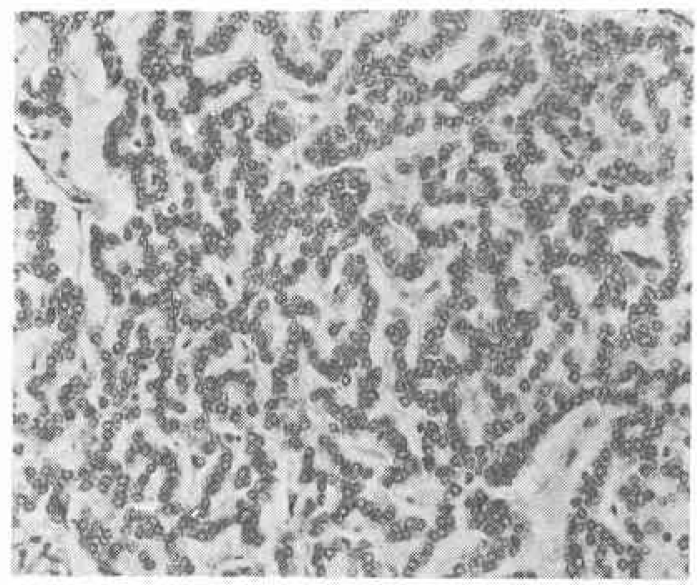

病理組織所見 : 腫瘍細胞は,リボンないし花網状排列 が明瞭で，核はクロマチンに乏しく，細胞質は弱エオジ ン好性である(圈6).

筋層に接した部で 1 部腺管構造を示している（図 5 ). 腫瘍細胞は，銀還元性染色 (Masson-Fontana) で陰性 であったが，好銀性染色 (Grimelius)により多くの腫瘍 細胞内に好銀性顆粒を認めた（図 7).

電䫓像では，図8のごとく，カルチノイドに特有な分 泌顆粒, 寸なわち限界膜をもった平均直径 200 〜 $300 \mathrm{~m} \mu$ の均一な球状顆粒を認める。

術後経過 : 術後経過は良好で, 術後 3 週目に退院した。 術後 4 年半経過した現在, 生存中で再発の徴候はない.

\section{IV 本邦報告例42症例の検討}

本邦に持ける直腸カチルノイドは，1967年上杉の第 1
図 7 好銀性染色 (grimelius) 腫瘳細胞内に好銀性 顆粒を多数認めた。

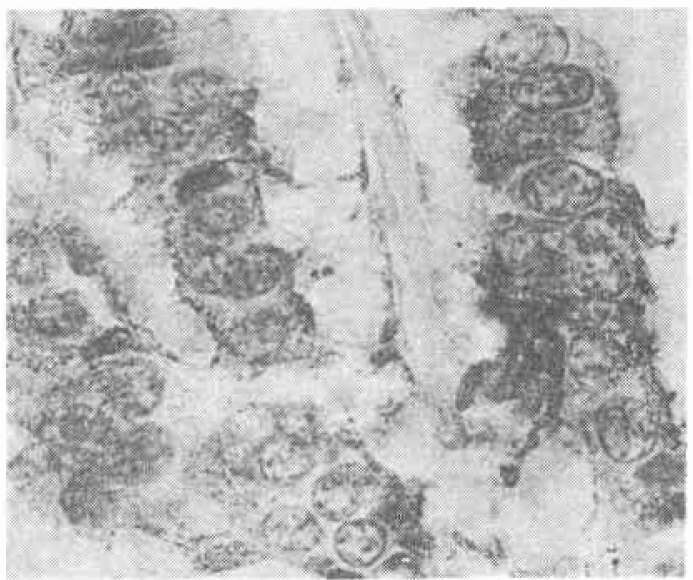

図 8 電顕像 $\times 15,000200 \sim 300 \mathrm{~m} \mu$ の均一な球状 顆粒が認められる

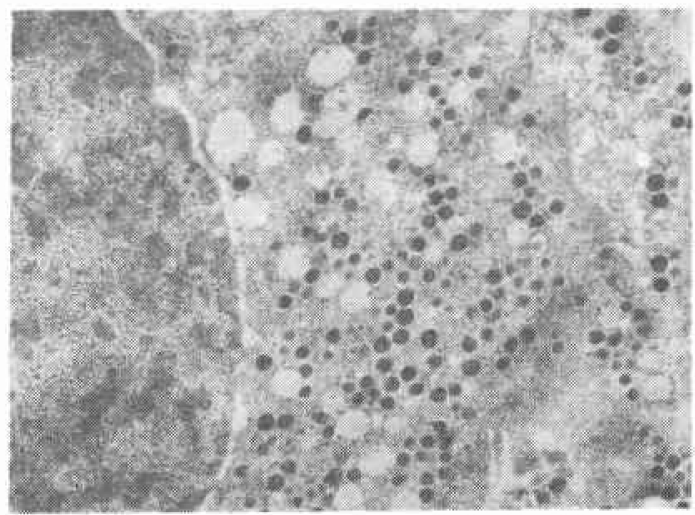

例目の報告以来，われわれの集計し得た正例は41例であ $丂^{27) \sim 52)}$.

われわれの症例を加えた42症例について検討を試み， 診断, 治療について述べたい。

表 2 は年鉤と性別についてみたものであるが, 不明例， 1 例を除くと男女比は 1.9で, Ponka ${ }^{24)} 1.4$, Orloff ${ }^{23)}$ 1.7, Caldarola ${ }^{22)} 1.23$ より 高率であるが，男性に多い 傾向がみられる，年齢は40歳代にピークがある.

Caldarola ${ }^{22)}$ は87\%が40歳代にみられたとして拈り， Ponka ${ }^{24)}$ は15歳女性の報告をし, Orloff ${ }^{23)}$ は珄比, 人 種の差異はないとしている。

表 3 は直腸カルチノイド患者の主訴であるが，腫瘍発 見の契機との関係において與味深い，記載のあった38例 中，肛門出血が19例（50\%）で多いが，多くは内侍核， 
表 2 直腸カルチノイド, 年令之性別

\begin{tabular}{c|r|r|r}
\hline 年 秢 & 男 & 女 & 計 \\
\hline $30 \sim 40$ 歳 & 8 & 2 & 10 \\
\hline $41 \sim 50$ & 9 & 7 & 16 \\
\hline $51 \sim 60$ & 6 & 3 & 9 \\
\hline $61 \sim 70$ & 4 & 2 & 6 \\
\hline 訫 & 27 & 14 & 41 \\
\hline \multicolumn{2}{|c}{ (不明 1 ) }
\end{tabular}

表 3 臨床症状

\begin{tabular}{|c|c|c|}
\hline 肛 門出血 & 19 & $50 \%$ \\
\hline 痛 & 6 & 15 \\
\hline 秘 & 4 & 10 \\
\hline 肛 陚 痛 & 2 & 5 \\
\hline 莉 & 1 & 3 \\
\hline テネスムス & 1 & 3 \\
\hline 腹 部 膨 満 & 1 & 3 \\
\hline 肛 門 脱 & 1 & 3 \\
\hline 無 症 状 & 3 & 8 \\
\hline 不 & 4 & \\
\hline 計 & 42 & \\
\hline
\end{tabular}

裂孔などを合併している場合が多く，下血例でも病变に ビラン，潰瘍を合瓶していない場合がほとんどであり， これらの症状はかならずしも本疾患に特有のものとは思 われない。

何らかの下部消化管，肛門部の症状があり，偶々直腸 指診, $\mathbf{X}$ 線検查, ロマノスコピー, 内視鏡検査でみつか る場合が注とんどである。Caldarola ${ }^{22)}$ は30\%が指診で 発見されたと報告している。われわれの症例のように胆 石症で来院し, 直腸指䛦で偶然, 発見されることるあ るので, 值腸指診の重要性をあらためて強調したい。 Orloff ${ }^{23)}$ は asymptomatic 32\%, 明らか飞他の疾患に上

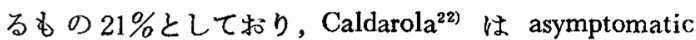
66\%としている.

表 4 は術施臨床部断名であるが，Carcinoid 之診断し たのは，17例で40\%が術前に診断されている.Ponka は17\% に術前診断可能であったとしている。

表 5 は直腸カルチノイドの発生部位を, 壁在性と肍門 部よりの距離で示したるのであるが，壁在性については 記載のないものが41例中11例にみられた。

肍門部よりの距離については，5～8cm に注とんぞ集 中しており，壁在性沉ついては，後壁，左側壁が約 $63 \%$
表 4 術前臨床診断

\begin{tabular}{|c|c|}
\hline カルチノイト & 17 \\
\hline 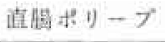 & 6 \\
\hline 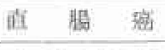 & 3 \\
\hline 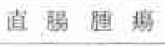 & 1 \\
\hline 不 & 15 \\
\hline at & 42 \\
\hline
\end{tabular}

表 5 直腸カルチノイドの発生部位

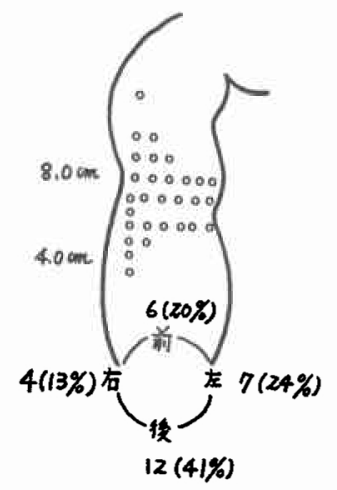

を占めているのが注目された. Caldarola ${ }^{22)}$ は $4 \sim 13 \mathrm{~cm}$ に99\%存在し，前壁と側壁に85\%みられたとして拈り，本 邦例との美は，検査時の体位に関係があるのではないか と思われる。Tiedemann ${ }^{25)}$ は壁在性はないとしている.

いずれにしても直腸指診を注意深く施行すれば，存在 診断は可能であり，通常の診察時の直腸指診の重要性を あらためて強調したい。

表6は病変の最大径と深達度および転移の関係をみた ものであるが, $1.0 \mathrm{~cm}$ 以内では13例中粘膜下層にとど まるものが 12 例 ( $92 \%)$ ，筋層飞およんでいるすのが 1 例（7\%）あるが転移を示した症例はない。

$1.0 \sim 2.0 \mathrm{~cm}$ では 6 例中粘膜下層にとどまるすのは 5 例 $(83 \%)$,筇層に怙上ぶものが1例 $(17 \%)$ で, リンパ 節転移を来したものが 1 例, 肝転移を来たし, 5-HIAA の上昇を示した例が 1 例 ${ }^{40)}$ あった。 したがって 1〜2cm では，25\%に転移がみられた. $2.1 \mathrm{~cm}$ 以上では，深達

表 6 腫瘤の最大径と転移と深達度

\begin{tabular}{l|r|r|r|r|c|c}
\hline \multirow{2}{*}{ 最大径 } & \multirow{2}{*}{ 数 } & 転 & \multicolumn{3}{|c}{} \\
\hline$<1.0 \mathrm{~cm}$ & 23 & 0 & 0 & 12 & 1 & 10 \\
\hline $1.0 \sim 2.0$ & 8 & 2 & 25 & 5 & 1 & 2 \\
\hline$>2.1$ & 8 & 7 & 8896 & 0 & 5 & 3 \\
\hline
\end{tabular}


度の記載のある 5 症例はすべて管層以上に浸潤がみら れ，転移は88\%にみられた。全体では，9/39 (23\%) に 転移がみられた。

Bates $^{26)}$ は234例で， $1.0 \mathrm{~cm}$ 以下に $1.7 \%, 1.0 \sim 2.0$

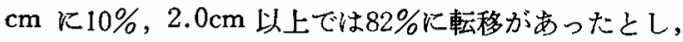
Tiedemann ${ }^{25)}$ は，それぞれ1.6\%，9.4\%，83\%と報告 している.

Orloff $^{23)}$ は0.1 $1.9 \mathrm{~cm}$ で $4.0 \%, 2.0 \mathrm{~cm}$ 以上で $93 \%$, Peskin and Orloff ${ }^{21}$ は40\%が悪性であったとしている.

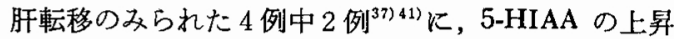
を認め, 両腸骨リンパ節，膵，腎，副腎に転移のみられ た 1 例にも，5-HIAA の上昇がみられた ${ }^{32)}$.

表 7は, ビラン, 潰瘍がみられた病変の最大径との 関係をみたものであるが，1.0cm 以内では23例中 1 例 (4.3) に, $1.0 \mathrm{~cm} \sim 2.0 \mathrm{~cm} 8$ 例中 4 例 $(50 \%)$ にビラ ン，演湯がみられ， $2.1 \mathrm{~cm}$ 以上では $63 \%$ ねられた。

Orloff $^{23)}$ は0.1 0.9cm では23例中, ビラン, 潰瘍は みられず，2.0cm 以上では，15例中 6 例 $40 \%$ にみら たとしている.

表 7 中心陥凹を伴う直腸カルチノイドの大きさ

\begin{tabular}{l|c|c}
\hline \multicolumn{1}{c|}{ 㩆大程 } & 数 & $\%$ \\
\hline$<1.0 \mathrm{~cm}$ & 1 & 4 \\
\hline $1.0 \sim 2.0$ & 4 & 50 \\
\hline$>2.1$ & 5 & 63 \\
\hline
\end{tabular}

表 8 中心陥凹を伴ら直腸カルチノイドの深達 度と転移

\begin{tabular}{|c|c|c|c|c|c|}
\hline & \multicolumn{3}{|c|}{ 梁達 度 } & \multicolumn{2}{|c|}{ 転 移 } \\
\hline & $\begin{array}{l}\text { 粘膜下層 } \\
\text { まで }\end{array}$ & 筋層以上 & 不 明 & リンパ節 & 肝 \\
\hline $\begin{array}{l}\text { 症 } \\
\text { 例 } \\
\text { 数 }\end{array}$ & 3 & 4 & 4 & 3 & 2 \\
\hline
\end{tabular}

表 8 は中心陷凹を伴ら直腸カルチノイドの深達度およ び転移についてみたものであるが，陷凹を有したものは 11例あり，5ち深達度の記載のある 7 例中, 粘膜下層に とどまるものは 7 例中 3 例 $(42.8 \%)$ で筋層以上のもの は7例中 4 例 $(57 \%)$ であった。

ビラン, 潰演がみられる場合, 転移率がどらかみてみ ると，11例中 5 例 (45\%) にみられた。

表9は直腸カルチノイドの銀反㾁をみたものである. 一般的には，直腸カルチノイドは，好銀反応，銀親和反 応いずれも陰性で, non reactive type が多いとされて きたがわれわれの集計では，42例中記載のある36例中 22例 $(61 \%)$ Kon reactive type がみられた.

しかし，好銀，銀親和反応いずれも陽性例が3例あ
表 9 直腸カルチノイドの銀反応

\begin{tabular}{|c|c|c|c|c|c|}
\hline 好銀反応 & + & + & & - & \multirow{2}{*}{ 不明 } \\
\hline 銀親和反応 & + & & + & - & \\
\hline 症 例 数 & $\begin{array}{c}3 \\
(8)\end{array}$ & $\begin{array}{c}9 \\
(25)\end{array}$ & $\begin{array}{c}2 \\
(6)\end{array}$ & $\begin{array}{c}22 \\
(61 \%)\end{array}$ & 6 \\
\hline
\end{tabular}

り，いすれれる生化学的に異常値を示したのは興味樑 (38) 40) (1).

最近の報告例は，最近開発されたより鋭敏な grimelius 法による好銀反応陽性例が増加しており，これは恐らく 従来慣用された Bodian, Davenport などによる好銀染色 を㬰施されたためと思われ，染色の任方にも問題がある のではないかと思われる。

表10は生化学と異常値を示した症例を示したものであ るが，全例男性で，直腸カルチノイドの平均年齡は40歳 代にピークがあるのに，5 例中 4 例が30歳代で，比較的 若く, しかも 5 例中 3 例に銀親和性，好銀性反応いずれ る陽性であるのは興味深い，腫瘍の大きさとの関連性は ないようである。

転移との関係は, 肝転移例 2 例, 後腹膜リンパ節, 勝，腎，副腎の広範囲の転移を来した症例 1 例で，他 2 例には転移はみられなかった。症例 3 ，症例 5 はそれぞ れ 5-HIAA と Gastrin, Serotonin と ACTH の上昇をみ ており, めずらしい症例で今後は Radioimmunoassay そ の他の導入により種々の活性物質ないしホルモンが容易 に測定可能となれば, Sjoerdsma ${ }^{20)}$ の提唱するカルチノ イドスペクトラムといら考えを前進させることになると 思われる.

表11は病変に対してどういら処置をしたかをみたる のであるが，腫場摘出を行ったものが16例 (38\%)を示 し, 直腸切断術, 前方切除術, pull through は直腸進行 癌に準じて根治術を施行したもので13例（30\%）を示し ている.人工肛門，手術不能例がそれぞれ 2 例づつで， 切除不能例は 4 例であり, 経過観察したものが 3 例みら れた。

直腸は外科解剖学的に特殊な部位にあるので, 前方切 除ができる部位は問題ないが, 根治性を求めて, 直腸切 断術を施行しなければならない場合は，人工肛門を造設 せねばならず，機能を保存しよらとすれば根治性に問題 がでてくるので，ぞのように対処すればよいのかむずか しい問題である。

本邦症例では， ほとんどが最近 $5 \sim 6$ 年以内の症例 で，予後の問題まで検討できないが，カルチノイド腫瘍 に対して，良性，悪性を組織学的に明確に判別すること 
表10 生化学上異常值を示した症例

\begin{tabular}{|c|c|c|c|c|c|c|c|c|}
\hline & 報告者 & 性 & 年路 & 主訴 & 腫榴の大きさ & 銀反地 & 転移 & 生化学検査 \\
\hline 1 & 村䀦 ${ }^{41}$ & $\delta$ & 47 & 下腹部痛 & $\begin{array}{r}4.0 \times 4.0 \\
\mathrm{~cm}\end{array}$ & $\begin{array}{l}\text { 好銀 (+) } \\
\text { 銀親和 (t) }\end{array}$ & 肝 & $\begin{array}{l}5 \mathrm{HIAA} \\
(17.9 \mathrm{mg} / \mathrm{\theta})\end{array}$ \\
\hline 2 & 植松 ${ }^{40)}$ & $\delta$ & 39 & テネスム & $1.8 \times 1.0$ & $\begin{array}{l}\text { 恏銀 }(t) \\
\text { 銀親和 }(+)\end{array}$ & $(-)$ & $\begin{array}{l}\text { セロトニン } \\
(91.7 \mu \mathrm{g} / \mathrm{dl}) \uparrow\end{array}$ \\
\hline 3 & $\equiv 木^{37\}}$ & $\hat{\delta}$ & 38 & 便 秘 & $3.0 \times 3.0$ & 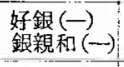 & 朋 & $\begin{array}{l}5 \mathrm{HIAA} \uparrow \\
\text { gastrin } \uparrow\end{array}$ \\
\hline 4 & 穴沢 ${ }^{38\}}$ & $\hat{\delta}$ & 35 & 肛門痛 & $0.4 \times 0.3$ & $\begin{array}{l}\text { 孥銀 }(+) \\
\text { 銀親和 }(+)\end{array}$ & $(-)$ & セロトニン \\
\hline 5 & 土田 ${ }^{321}$ & $\gamma$ & 33 & 肛門痛 & $4.0 \times 4.0$ & $\begin{array}{l}\text { 恏銀 }(-\rightarrow) \\
\text { 銀親和 }(+)\end{array}$ & 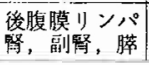 & $\begin{array}{l}\text { セロトトン } \\
\mathrm{ACTH} \uparrow\end{array}$ \\
\hline
\end{tabular}

表11 直腸カルチノイドの治療方針

\begin{tabular}{|c|c|}
\hline 腄䒇摘出術 & 16 \\
\hline 直晹切断術 & 10 \\
\hline 前方切除俪 & 2 \\
\hline 人工肛門 & 2 \\
\hline 手桩不能 & 2 \\
\hline Pull through & 1 \\
\hline 㳗调钼繁 & 3 \\
\hline 不 明 & 6 \\
\hline it & 42 \\
\hline
\end{tabular}

は不可能で, 臨床的悪性度を, 他葴器への浸潤, リンパ 節転移, 遠隔転移の有無できめている ${ }^{23)}$ 現状では，その 腫瘍の大きさと, 深達度がその予後に大きな意味をもっ ている (表6) 21) 26).

欧米の follow up による結論として, $1.0 \mathrm{~cm}$ 以下の 症例に対しては fulguration または local excision, 1.0 $\sim 2.0 \mathrm{~cm}$ は, wide local excision, $2.1 \mathrm{~cm}$ 以上は根治術 を行らべきとする報告が多く ${ }^{21 \sim 26)}$ ，また2.0cm 以下で も, 笳層以上への浸潤が疑われたり, 転移が疑われる場 合は踌躇することなく根治術を行うべきである。

次に大切なことは，保存的処置を行った症例に対して は, 頻回に follow up し, 局所の再発の有無を check することが肝要である.

\section{$\mathbf{V}$ 結 語}

1) カルチノイド腫濝の歴史的背景の概略をのべた。

2） 62 歳男性の, $1.8 \times 1.5 \mathrm{~cm}$ の直腸カルチノイドに 直腸切断術を施行した 1 例を報告した。リンパ節転移は なく，生化学的にもとくに異常値はみられなかった。

腫瘍細胞は Grimerius 法で好銀性顆粒を多数認め, 電 顕像で200〜 300 $\mathrm{m} \mu$ の球状顆粒を認めた。術後 5 年再癹 の徵候はない,

3）直腸カルチノイドの本邦報告42例について臨床病 理学的検討を加えた。
その結果, 男女比は1.9で男性に多く，40歳代にピー クがあった．主訴としては肛閒出血が50\%を占めたが， 尰瘍と直接関係のある特異的症状とは思われなかった。

発生部位は，肛門部より $5.0 〜 8.0 \mathrm{~cm}$ にはとんど集中

して扣り，後壁，左側壁が63\%を占めた.

腫瘍の最大径と転移との関係は， $1.0 \mathrm{~cm}$ 以下では転 移なく，1.0 2.0 cm では $25 \%$ に，2.0cm 以上では $88 \%$ に転移がみられた。

腫瘍にビラン，潰瘍がみられる場合は45\%に転移がみ られた。

生化学的異常値を示した症例はいずれも男珄で 5 例あ り，ちち 3 例に銀親和性，好銀性反応いずれる陽性を示 したのは興味深い.

自験例は第28回日本大腸肛門病学会において報告し た。な怙自験例の病理組織学的検索については，九大第 2 病理，遠城寺宗知教授に感謝の意を表する.

\section{文献}

1) Merling, F.: Anatomie Pathologique de l'appendice du caecum. Expersence (Paris), 1: $337-$ 1838.

2) Lubarsch, O.: Über den primären Krebs des Ileum nebst Bemerkungen über das gleichzeitige Vorkommen von Krebs und tuberkulose, Virchow's Arch. Path. Anat., 111: 280-317, 1888.

8) Oberndorfer, S.: Über die kleinen Dündarmcarcinome. Verh. Dtsch. Ges. Pathol., 11: $113-116,1907$.

4) Saltykow, S.: Über die Genese der K"arzinoiden Tumoren" so wie der "Adenomyome" des Darms, Beitr. Path. Anat., 54: 559-594, 1912.

5) Gosset, A. and Masson, P.: Tumeurs Endocrines de l'appendice. Presse Med, 25: 237-240, 1914.

6)建石竜平ほか：Carcinoid Tumor，日本癌学会合 同シンポジゥム記録, $169 \sim 182,1970$.

7) Lembeck, F.: 5-Hydroxytryptamine in a carcinoid tumour. Nature, 172: 910-911, 1953.

8) Williams, E.D. et al.: The classification of carcinoid tumor. Lancet, I: 238-239, 1963. 
9) Black, W.C.: Enterochromaffin cell types and corresponding carcinoid tumors. Lab. Invest., 19: $473-486,1968$.

10) Soga, J. and Tazawa, K.: Pathologic Analysis of carcinoids. Histologic reevalucation of 62 : cases. Cancer, 28: 990-998, 1971 .

11) Bates, H.R. et al.: Composite carcinoid tumor of the colon. Dis. Colon and Rectum., 10: 467-470, 1967.

12) Hernandez, F.J. et al.: Mixed carcinoid and mucus secreting intestinal tumors, Arch. Path., 88: $489-496,1969$.

13) Klein, H.Z.: Mucinous carcinoid tumor of the vermiform appendix, Cancer, 33: 770-777, 1974.

14) Toker, C.: Observation on the composition of cerfain colonic tumors, Cancer, 24: 256-260, 1969.

15) Kubo, T. and Watanabe, H.: Neoplastic argentaffin cells in gastric and intestinal carcinomas. Cancer, 27: 447-454, 1971.

16) Watanabe, H.: Argentaffin cells in adenoma of the stomach, Cancer, 30: 1267-1274, 1972.

17) Pearse, A.G.E.: The cytochemistry and Ultrastructure of polypeptide hormoneproducing cells of the APUD series and the embryologic, physiologic and pathologic implications of this concept. J. Histochem. Cytochem., 17: 303-313, 1969.

18) Sanders, R.J.: Carcinoids of the gastrointestinal tract. C.C. Thomas Publ. Springfield, Illinois, U.S.A., 1973.

19）阿部圭志：カルチノイドの臨床一本邦例の検 討。日本癌学会合同シンポジム記録, 162$168,1970$.

20) Sjoerdsma et al.: The carcinoid spectrum. Gastroenterology., 47: 104-107, 1964.

21) Peskin, G.W. and Orloff, M.J.: A clinical study of 25 patients with carcinoid tumors of the rectum, Surg. Gynec. Obst., 109: 673-683, 1959.

22) Caldarola, V.T. et al.: Carcinoid Tumor of the Rectum. Amer. J. Surg., 107: 844-849, 1964.

23) Orloff, M.J.: Carcinoid Tumors of the rectum, Cancer, 28: 175-182, 1971.

24) Ponka, J.L. et al.: Carcinoid Tumors of the rectum. Dis. Colon Rectum, 14: 46-56, 1971.

25) Tiedemann, R.N. et al.: Carcinoid tumor of rectum, New York Sate J. Med. March, 1: $559-$ $563,1972$.

26) Bates, H.R. Jr.: Carcinoid tumors of the rectum. Dis. Colon Rectum, 5: 270-280, 1962.

27）上杉雄三他：直腸カルチノイドの1例. 日本大 晹肛門学会誌, $21: 58-59,1967$.

28）林 四郎他：横行結䭪之直晹カルチノイド。日 本消化器病学会誌, $65: 308,1968$.

29）山際裕史：胃癌と直腸カルチノイドの合併例,
臨床外科, $25: 999 \sim 1004,1970$.

30）相野田芳教他：直腸巨大カルチノイドの1例. 外科, $32: 757-760,1970$.

31）佐分利六郎他：直腸カルチノイドについて。治 療, $52: 2311-2317,1970$.

32) 土田 博他：七ロトニンと ACTH の産生を伴 つた值腸カルチノイド。医学のあゆみ、79: 697-706, 1971 .

33) 阿部圭志他：カルチノイド腫演の生化学的研 究。癌の臨床, 19：980-985,1973.

34) 笹村雅人他: 直腸カルチノイドの 2 例. 日本大 腸肛門学会誌, $23: 24-26,1971$.

35) 井上 勇 : 日本大腸肛門学会誌 (追加発言), $23: 25,1971$.

36) 河野一男: 日本大晹肛門学会誌 (追加発言), $23: 25,1971$.

37）三木一正他：巨大な肝転移と有棘赤血球を伴つ た直腸カルチノイドの1例. 内科, $30: 1154$ 1162, 1972.

38) 穴沢貞夫他：直腸カルチノイドの 1 例. Progress of digestive Endoscopy, 2 : 100-101,1973.

39）佐藤八郎他：直晹カルチノイド。臨床之研究, 50 : 310-316, 1973 .

40）植松羕和他：直腸カルチノイドの 1 治験例。日 本大腸肛門学会誌, 26 : 209-210, 1973

41）村田原庸他：佂腸悪性カルチノイドの 2 例。外 科診療, $15: 1524-1528,1973$.

42）山崎軍治他：住晹カルチノイドの経験例。外科 診療, 16：435-438, 1974.

43）生沢啓芳他：菣腸カルチノイドの1例，胃と 腸, $9: 789-794,1974$.

44）安藤幸史他：著明な肝転移を来した值腸カルチ ノイドの 1 例。 日本大腸肛門学会誌, $28: 29$ 30, 1975.

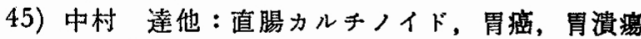
を合併した 1 症例. 臨床外科, $30: 1199-1203$, 1975.

46) 桶上 駿他：直腸 カルチノイドの 1 例. 胃と 腸, 10: 651一 $655,1975$.

47）太田陽一他：消化管カルチノイドの 2 例. 臨床 外科, 30:913-918, 1975.

48）福留 厚他：直腸カルチノイドと $\mathrm{S}$ 字状結腸癌 の併存せる 1 症例. 臨床外科, $30 ： 127-131$, 1975.

49) 中川原義三他 : 直腸カルチノイドの治験例. 瘦 の臨床, $21 ： 632-635,1975$.

50) 升森茂樹他：直腸カルチノイド，5症例の䠦 床病理学的検討. 癌の臨床, 21: 1181-1188, 1975.

51）舟田彰他：直腸カルチノイドの診断. 胃と 腸, 10： 597-607, 1975.

52）高木正隆他：直腸カルチノイドの 1 例. 胃と 腸, $11: 1175-1181,1976$.

53) 佐々木英制他：直腸カルチノイド，臨床外科, $30: 1309-1313$, 1975. 